\title{
The Notary Role / PPAT in Improving Legal Awareness Society to Perform Registration Rights to Land Based on Government Regulation No. 24 of 1997 on Land Registration
}

\begin{abstract}
Widyawati $^{1}$, Tafta Aji Prihandono ${ }^{2}$ and Widhi Handoko ${ }^{3}$
Abstract. The purpose of this study: 1) to analyze the Notary role / PPAT in raising legal awareness in the registration of land rights in Pati Regency, according to Government Regulation No. 24 of 1997 on Land Registration. 2) to analyze the obstacles and solutions role of the Notary / PPAT in increasing of public awareness for the registration of land rights in Pati regency. The data used in this study are primary data, secondary data and data that can support tertiary study, which was then analyzed by descriptive analytical method.

Based on the results of data analysis concluded that: the role of the Notary / PPAT in increasing of public awareness for the registration of land rights in Pati Regency, according to Regulation No. 24 of 1997 on Land Registration can be said to have not been successful, due to the lack of socialization of Notary / PPAT up to the suburbs Pati city where people still common law. Barriers Notary / PPAT in increasing of public awareness for the registration of land rights in Pati regency namely external and internal factors. The solution Notaries should cooperate with other parties for the success of socialization, such as cooperation with the press. Keywords: Notary Role; Socialization; Legal Understanding.
\end{abstract}

\section{Introduction}

Land not only serve as a beachhead, but more than that, the ground is where the growth of the importance of soil life that role no longer is a matter of debate. In other words, everyone agreed that the land is very important to then instead arise various problems related to land it, especially in the form of a land dispute. Based on data Badilum Supreme Court (MA), in the period of 2017 there were 14446 caseload related to land disputes.

According to the Basic Agrarian Law, one of the ways that are considered effective for preventing or at least minimizing land disputes is by registration of land rights. Therefore at the Article 19 paragraph (1) of the BAL, stated that "In order to ensure legal certainty by the Government held land registration throughout the territory of the Republic of Indonesia in accordance with the provisions stipulated in Government Regulation." 4

Legal certainty in Article 19 paragraph (1) BAL is intended to eliminate uncertainty, which in turn give rise to a legal dispute over land. Although his stay was realized that the registration of land rights was not able to completely eliminate land disputes (and even in some cases, registration of land rights would trigger land

\footnotetext{
${ }^{1}$ Student of Master of Notary Law Faculty of Law, Universitas Islam Sultan Agung email widya1118@gmail.com

2 Students of Master of Law, Faculty of Law, Universitas Islam Sultan Agung email tft 14w@yahoo.co.id

${ }^{3}$ Notaris/PPAT in Semarang City

${ }^{4}$ Act of Basic Agrarian Article 19 paragraph (1).
} 
disputes), registration of land rights still viewed positively in order to achieve the basic values of law is certainty, fairness and expediency.

On Government Regulation No. 10 of 1961 on land registration, land deed official name is not standardized or it can simply be said to be unknown even substantially, the functions of the land deed official there and play a significant role. In Article 19 states that every agreement that is intended to transfer the land, give something new rights over land, mortgaged land or borrow money and land rights as dependents, must be evidenced by a deed made by and in the presence of officials appointed by the Minister of Agrarian (hereinafter in this regulation called: acting). The deed stipulated by the Ministry of Agrarian shape. The description in the article is seen as less obvious and less firmly so that the Regulation no.

Through inheritance, separation and new entitlements, the number of parcels of land are eligible for registration is expected to rise to around 75 million. Things are a constraint in the implementation of land registration, in addition to budget shortfalls, tools and personnel, is a state objective ground its own land which in addition to its large and spread over a wide area, most of its control are not supported by the means of proof are easily obtained and be credible. Another problem is the legal requirement to base the implementation of land registration is felt not enough to give the possibility for proper registration in a short time with a more satisfactory results.

In connection with the various problems mentioned above, in order to improve a better support to national development, it is necessary to conduct improvements to the conditions governing the registration of land. It is intended to provide legal certainty in the land sector, which is in fact at that time scattered in many laws and regulations. Finally, on July 8,1997 , the Government enacted Government Regulation No. 24 of 1997 on Land Registration which revoked the previous regulation Government Regulation No. 10 of 1961 on Land Registration.

Government Regulation No. 10 of 1961 which consists of eight chapters and 46 Articles deemed no longer sufficient to resolve the agrarian question related to land registration and even considered just a lot of it presented numerous new problems. Although not perfect Government Regulation No. 24 of 1997 which consists of ten chapters and 66 Article seen as more comprehensive in addressing the issue of registration of land.

General provisions of Regulation no. 199724 Figure 24 explicitly states that the Land Deed Official, hereinafter called PPAT is a public official who is authorized to make the deeds of certain land. But in the PP not elaborate further on PPAT. It was only on March 5, 1998 with the enactment of Regulation no. 37 of 1998 on the Regulation of Land Deed Official Position, position PPAT was ablaze. ${ }^{5}$

\footnotetext{
${ }^{5}$ On June 22, 2016 was revised by Government Regulation No. 24 of 2016 regarding Amendment to Government Regulation No. 37 of 1998 on the Regulation of Land Deed Official Position. The main objective of the government regulation change is in order to support the deregulation policy of agrarian / land in order to accelerate the implementation of the Government's Economic Policy Package.
} 
Further to enhance the role of the Land Deed Officer as well as to improve services to the public land registration was issued Government Regulation No. 24 of 2016 regarding Amendment to Government Regulation No. 37 of 1998 on the Regulation of Land Deed Official Position. However, the role of the Notary / PPAT in increasing of public awareness for the registration of land rights is considered still vague so authors interested in applying for a research proposal entitled " The Notary Role / PPAT In Improving Legal Awareness Society To Perform Registration Rights To Land Based On Government Regulation No. 24 of 1997 on Land Registration In The Pati Regency."

The objectives of the study were: 1 ) to determine the role of the Notary / PPAT in raising legal awareness in the registration of land rights in Pati Regency, according to Government Regulation No. 24 of 1997 on Land Registration; and 2) to assess the barriers and solutions role of the Notary / PPAT in increasing of public awareness for the registration of land rights in Pati regency. The data used in this study are primary data, secondary data and data that can support tertiary study, which was then analyzed by descriptive analytical method.

\section{Research methods}

The method used is the juridical-normative research method. Juridical-normative research method is a method of legal research based on norms / principles of positive law to break down once to answer a problem as it exists. The approach used in this research is descriptive analysis approach, descriptive analytical research takes issue or focus on issues as presently conducted research. The result of research which is then processed and analyzed for the conclusions drawn. Is said to be descriptive because it aims to obtain an objective presentation of the analysis of the notary's role in increasing of public awareness for the registration of land rights in the district of starch under Regulation No. 24 of 1997 on land registration. The data used in this study are primary data, secondary data and data that can support tertiary study, which was then analyzed by descriptive analytical method.

\section{Results and Discussion}

\subsection{The Notary Role / PPAT In Increasing Of Public Awareness For The Registration Of Land Rights In Pati Regency, According To Government Regulation No. 24 of 1997 on Land Registration.}

Indonesia as a state of law, the legal consciousness like all components of the nation become something must to be met, including legal awareness for the community to carry out registration of land rights. In order to improve legal awareness for the community to register rights to land owned, then the role of the Notary in accordance with his duty to take responsibility for the community legal awareness through counseling. This right is in accordance with the code of conduct Notary containing the values of a general nature, Article. 3, (figure 3. 2) which reads: "Notary in the conduct of their office provides legal counseling to achieve a 
high legal awareness in the society so that people recognize and encourage the rights and obligations as citizens and members of society" 6

Provide legal counseling to the community can be seen as a form of service that is fundamental and must be performed by a Notary, due to the public awareness for registering land rights can provide benefits to all parties. For the people have legal certainty to land his property, and for the institution to have an increase of income, so as to advance and develop as well as for employees of Notaries of improved welfare.

Legal counseling in the community to raise awareness of the law for PPAT Notary be something very urgent. PPAT Notary services, the user is society. The higher awareness to register their land rights, the institution will be flooded notary public to use the services of a PPAT Notary in order to obtain a certificate of his land, and vice versa.

So the other side of the law on public education by PPAT Notary can serve as a media campaign, so that marketing activities be increased effectiveness. This condition has been a source of both parties the benefit of both parties and their PPAT notary its employees and society in general. Legal counseling as an activity that is commendable and noble religion can be positioned as Amar Ma'ruf Nahi Munkar that invite to good and prevent evil. This has positive impact and benefits as well as educate. Even more than that, legal counseling also can be an instrument of propaganda to educate the nation that is one of our country's constitutional mandate of the Republic of Indonesia.

\subsection{Obstacles And Solutions Of The Notary Role / PPAT In Increasing Of Public Awareness For The Registration of Land Rights In Pati Regency.}

Each activity when facing obstacles, there should be an attempt to overcome these obstacles as a form of solution. There is never a solution, if there are no obstacles, so the bottleneck with existing solutions reciprocal correlation and this also applies to the law on public information activities in order to raise awareness of the law, especially in registering land rights be hers.

Barriers legal counseling that occurs as part of the role of the PPAT Notary can be tracked from the social psychology theory, according to Bimo Walgito in his book on social psychology that human behavior is determined by two factors, namely internal and external. The internal factor is the individual's own, while the external is everything that exists in the environment of the individual. ${ }^{7}$ Legal counseling activities by the notary is a human behavior is influenced by internal factors, namely PPAT Notary and external personnel ie personnel PPAT Notary conditions beyond itself.

\footnotetext{
${ }^{6}$ Liliane Tedjosaputro. 2012. Etika Profesi Notaris Dalam Menegakkan Hukum Pidana. Yogyakarta : PT. Bayu Indra Gratika, p. 124

${ }^{7}$ Bimo Walgito, 1994. Psikologi Sosial. Yogyakarta: Andi Offset, p 17.
} 
Internal factors such sas the motivation of the personnel / PPAT Notary, and the ability of both the ability of Human Resources, funds and infrastructure. While the external constraints are the aspirations of the people and Non Government Organization which very rarely even propose no legal counseling on governments and institutions notaries.

The solution to this obstacle is eliminating bottlenecks. The results of the study can be input to the head of the division of local government through the law and Parliament to overcome barriers for public legal education needs and facilitate the Non Government Organization to be empowered to increase legal awareness through legal counseling.

\section{Closing}

\subsection{Conclusion}

Based on the research results can be concluded as follows:

- The role of the Notary / PPAT in increasing of public awareness for the registration of land rights in Pati Regency, according to Government Regulation No. 24 of 1997 on Land Registration can be said to have not been successful, due to the lack of socialization of Notary / PPAT evenly to the outskirts of the town of Pati where the community is still blind to the law.

- Barriers Notary / PPAT in increasing of public awareness for the registration of land rights in Pati regency namely external and internal factors. The solution to this obstacle is eliminating bottlenecks. The results of the study can be input to the head of the division of local government through the law and Parliament to overcome barriers for public legal education needs and facilitate the Non Government Organization to be empowered to increase legal awareness through legal counseling.

\subsection{Suggestion}

- For Notary. Notary must establish cooperation with other parties in order to increase legal awareness for registration of land rights in Pati regency, such as cooperation with media workers, to participate mensosilasikan importance of registering land rights so as not to stumble later legal dispute.

- For the Government. The government, whether in this case the executive and legislative branches, should help drive efforts to increase legal awareness, through education and regulation.

- For the Community. People are expected to actively search for information about the legal ownership of the land that is not easily stumble dispute. People are expected to always be open to new information.

\section{Bibliography}

\section{Books}

[1] A.P. Parlindungan, 2009, Pendaftaran Tanah di Indonesia (PP No 37 tahun 1997), cetakan keempat, Penerbit Mandar Maju, Bandung. 
[2] Abdurrahman, 1983, Beberapa Aspek Tentang Hukum Agraria, Alumni, Bandung.

[3] Boedhi Harsono, 2008, Hukum Agraria Indonesia: Sejarah Pembentukan Undang-Undang Pokok Agraria, Isi dan Pelaksanaannya, Djambatan, Jakarta.

[4] Maria S.W. Sumardjono, 2008, Tanah Dalam Perspektif Hak Ekonomi Sosial dan Budaya, Kompas, Jakarta.

[5] Peter Blau dan Marshlml W. Meyer, 1987, Birokrasi Dalam Masyarakat Modern, Universitas Indonesia, Jakarta

[6] Widhi Handoko, 2014, Kebijakan Hukum Pertanahan: Sebuah Refleksi Keadilan Hukum Progresif, Thafa Media, Satjipto rahardjo Institute, Yogyakarta.

\section{Legislation}

[1] Constitution of the Republic of Indonesia of 1945

[2] Code of Civil law

[3] Act of Agrarian

[4] Act No. 5 of 1960 on Basic Regulation of Agrarian Principles (State Gazette of the Republic of Indonesia of 1960 Number 104, Supplement to State Gazette of the Republic of Indonesia Number 2043);

[5] Government Regulation No. 24 of 1997 on Land Registration (State Gazette of the Republic of Indonesia of 1997 Number 59, Supplement to the State Gazette of the Republic of Indonesia Number 3696);

[6] Government Regulation No. 37 of 1998 on the Position Rules Deed Official Land as amended by Government Regulation No. 24 of 2016 regarding Amendment to Government Regulation No. 37 of 1998 (Official Gazette of the Republic of Indonesia of 2016 Number 120, Supplement to the State Gazette of the Republic of Indonesia Number 5893) 